\title{
THERMOGRAVIMETRIC ANALYSIS OF ANNINGRE TANNIN RESIN
}

\author{
Noel Konai ${ }^{1, \diamond}$, Danwe Raidandi ${ }^{1,4}$, Antonio Pizzi ${ }^{2,3}$, Pierre Girods $^{2}$, Marie-Christine Lagel ${ }^{2}$, \\ Melhyas Kple
}

\begin{abstract}
Three formulations of aningre tannin resins containing in order the paraformaldehyde powder, hexamethylenetetramine and aqueous glyoxal as hardeners were developed. Their thermogravimetric analysis have shown that they begin to decompose respectively from $135^{\circ} \mathrm{C}, 145^{\circ} \mathrm{C}$ and $140^{\circ} \mathrm{C}$. About 24\%, 40\% and $39 \%$ solid residues of their initial masses exist at the end of the analysis. Thermomechanical analysis has shown that the formulation containing paraformaldehyde powder as hardener has the best rigidity and the worst contains the hexamethylenetetramine. All formulations have different thermal degradation, differences were more significant between 400 and $900^{\circ} \mathrm{C}$. The decomposition of hardeners become more significant from $400^{\circ} \mathrm{C}$.
\end{abstract}

Keywords: Aningre tannin resins, decomposition, residues hardeners, thermogravimetric analysis, temperature, thermomechanical analysis.

\section{INTRODUCTION}

Some plants constituents such as cellulose, lignin and tannin are increasingly used today in the manufacture of bio - adhesives to replace synthetic resins such as those based on formaldehyde, epoxides. Several reviews have appeared on such a subject: The recent developments in eco - efficient bio - based adhesives for wood bonding was reviewed (Pizzi 2006). The structural beams from thick wood panels bonded industrially with formaldehyde - free tannin adhesives was presented (Pichelin et al. 2006) and the development and characterization of adhesives from soy protein for bonding wood (Yuan and Kaichang 2007). The mastery of the characteristics and behaviors of tannins adhesive has become nowadays a concern for many researchers. Thermogravimetric (TGA) analysis is one of the methods most used in polymer characterization. Thus, the TGA of maritime pine tannin and maize flour adhesive has been studied (Moubarik et al. 2010) and identified a tannin/maize flour decomposition zone around $225^{\circ} \mathrm{C}$ (Moubarik et al. 2010). Tannin - formaldehyde adhesive used for the manufacture of plywood and particleboards (Coppens 1980) have started to be studied already some time ago. The mechanism of the polyphenolic tannin resin and hexamethylenetetramine as hardener (Pizzi and Tekely 1995), liquefied wood as a partial substitute of melamine-urea-formaldehyde and ureaformaldehyde resins (Esteves et al. 2015), furanic copolymers with synthetic and natural phenolic materials for wood adhesives (Abdalla et al. 2015) and the thermal analysis of wood particles with low combustion (Reh et al. 1993) have also been studied. Equally, Blazek, has studied the reaction kinetics of the thermal degradation of polymers (Blazek 2005) and Lin et al. (2014) have studied the preparation and properties of phenol-formaldehyde-chinese fir liquefaction copolymer resin.

${ }^{1}$ Laboratory of Materials Mechanics, Structures and Productiques, National Advanced School of Engineering, University, Yaoundé 1, Yaounde, Cameroon.

${ }^{2}$ ENSTIB - LERMAB, Nancy University, Epinal, France.

${ }^{3}$ Dept. of Physics, King Abdulaziz University, Jeddah, Saudi Arabia.

${ }^{4}$ Laboratory of Mechanic, Materials and Building, Sahel Institute of Maroua University, Maroua, Cameroon.

"Corresponding Author : noel.konai@yahoo.fr

Received: 18.03.2015 Accepted: 16.12.2015 
Nowadays, some problems still exist in the uses of tannin as adhesive. This is the case of viscosity, the differences in reactivity between different tannins, stiffness, cross-linking level and degradation temperature between differents tannins and adhesives formulations (Pizzi 1994, Pizzi 2006). In this paper, a new tannin extract from a plant called Aningre or Abam (superba aningre) in Cameroon is characterized for its use as an adhesive in the wood industry. It is therefore important to determine the upper limits of temperature at which the aningre tannin resin can be submitted without risks, to determine their decomposition points and rigidities.

\section{MATERIALS AND METHODS}

\section{Resin development}

Aningre is a procyanidin type tannin. To extract it, Aningre ground bark was introduced in a water solution containing $2 \%$ sodium bisulfite and $0,5 \%$ sodium bicarbonate (water: bark ratio was $6: 1$ based volume). All solution was introduced in a bath water, under continuous stirring at $60^{\circ} \mathrm{C}$ during 4 hours. Then, proceed to separation and filtration to get a reddish black liquid and a solid residue. Recovered liquid fraction was then concentrated at $60^{\circ} \mathrm{C}$ using a rotary evaporator, then it was frozen using liquid nitrogen and laboratory spray drier. A tannin powder, easier to use for analysis and storage was finally obtained (Sealy-Fisher and Pizzi 1992, Kireche 2012).

To develop the resin, an aqueous solution containing $40 \%$ of tannin $+\mathrm{n} \%$ of hardener based weight tannin (n vary depending formulations) was placed into a beaker and the $\mathrm{pH}$ adjusted to 12 by adding $\mathrm{NaOH}$. All components were mixed mechanically until the viscosity reached $750 \mathrm{mPa}$ s. The viscosity was measured with a Brookfield RV viscometer.

Three formulations were developed:

Formulation 1 or PF: An aqueous solution containing $40 \%$ aningre tannin extract was mixed with $5,5 \%$ of paraformaldehyde powder based weight tannin and the $\mathrm{pH}$ was adjusted to 12 adding a sodium hydroxide water solution (solution concentration of $\mathrm{NaOH}$ was $33 \%$ ).

Formulation 2 or $\mathbf{H}$ : An aqueous solution containing $40 \%$ aningre tannin was mixed with $6.5 \%$ of hexamethylenetetramine based weight tannin and the $\mathrm{pH}$ was adjusted to 12 adding a sodium hydroxide water solution (solution concentration of $\mathrm{NaOH}$ was $33 \%$ ).

Formulation 3 or Gly: An aqueous solution containing 40\% aningre tannin extract was mixed with $12 \%$ of aqueous glyoxal based weight tannin and the $\mathrm{pH}$ was adjusted to 12 adding a sodium hydroxide water solution (solution concentration of $\mathrm{NaOH}$ was $33 \%$ ).

\section{Thermogravimetric analysis (TGA)}

Thermogravimetric analysis (TGA) was done using NETZSCH STA 449F3 Jupiter (Germany) equipment. About $100 \mathrm{mg}$ of each cured samples was placed on a balance located in the furnace and heat was applied over the temperature range from 20 to $900^{\circ} \mathrm{C}$ at a heating rate of $5^{\circ} \mathrm{C} / \mathrm{min}$ during 30 min in argon gas. Weight gain (TG curves) and rate of mass loss (DTG curves) of each formulations were determined.

\section{Rigidity of aningre tannin resins}

The rigidity of different formulations of resin was compare using thermomechanical analysis (Navarrete et al. 2011). The maximum of the curve (MOE depending temperature) was considered as the peak in Modulus of Elasticity (MOE). A METTLER TOLEDO TMA 40 (Orangeburg NY, USA) equipment was used for the analysis. 


\section{RESULTS AND DISCUSSION}

\section{Pyrolysis of formulation 1 resin}

Figure 1 shows the TG and DTG curves of the aningre tannin resin (formulation 1). The pyrolysis of this resin (formulation 1) shows three main regions of mass losses: The first region between $40^{\circ} \mathrm{C}$ and $135^{\circ} \mathrm{C}$ with the peak at $49^{\circ} \mathrm{C}$ due mainly to loss of absorbed water and trace formation of volatile compounds such as $\mathrm{CO}$ and $\mathrm{CO}_{2}$ released by the resin. The second region between $135^{\circ} \mathrm{C}$ and $675^{\circ} \mathrm{C}$ with the peak around $255^{\circ} \mathrm{C}$ is due to the degradation of laterals resin chains (Zhang et al. 2011). In fact, between $135^{\circ} \mathrm{C}$ and $255^{\circ} \mathrm{C}$, tannin starts to decompose and releases $\mathrm{CO}_{2}$ and $\mathrm{CO}$ at $215^{\circ} \mathrm{C}$. The decomposition which occurs around $299^{\circ} \mathrm{C}$ is due to the auto - inflammation of paraformaldehyde releasing $\mathrm{CO}, \mathrm{CO}_{2}$ and hydrogen (Anachemia 2012). Around $480^{\circ} \mathrm{C}$, paraformaldehyde releases $\mathrm{CO}$ and $\mathrm{CO}_{2}$ also. The third region of mass loss between $675^{\circ} \mathrm{C}$ and $765^{\circ} \mathrm{C}$ with the peak around $720^{\circ} \mathrm{C}$ is due to the decomposition of rigid segments in the resin (Yoshio et al. 2003) with a release of $\mathrm{CO}, \mathrm{CO}_{2}$, $\mathrm{CH}_{4}$ and carbon formation. It should be noted that the decomposition was not total, about $24,01 \%$ of initial mass stays there.

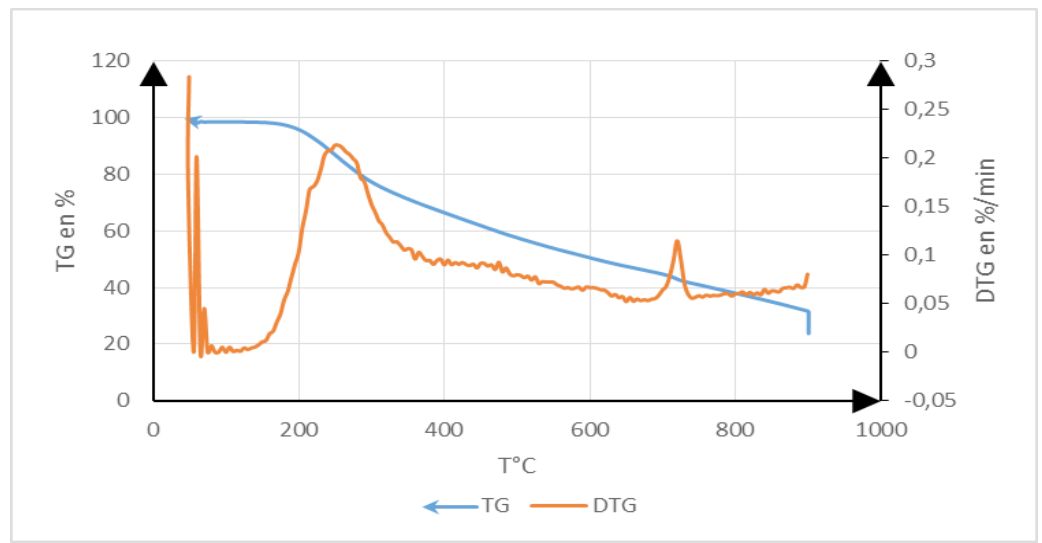

Figure 1. TG and DTG curves of pyrolysis analysis of aningre tannin resin under formulation 1.

\section{Pyrolysis of formulation 2}

Figure 2 shows the TG and DTG curves of formulation 2 of aningre tannin resin. The first region of weight loss (formulation 2) occurs between $40^{\circ} \mathrm{C}$ and $145^{\circ} \mathrm{C}$ with the peak around $49^{\circ} \mathrm{C}$. This loss is due to the evaporation of absorbed water and the formation of small volatile combustible compounds $\left(\mathrm{H}, \mathrm{CO}, \mathrm{CO}_{2}\right)$ released by the resin (formulation 2). The second region between $145^{\circ} \mathrm{C}$ and $590^{\circ} \mathrm{C}$ with the peak around $250^{\circ} \mathrm{C}$ is due to the degradation of laterals chains of the resin (Zhang et al. 2011, Petrovich et al. 1994) and to the formation of volatile combustible compounds released by hexatramethylenetetramine. The mass loss registered in the region between $590^{\circ} \mathrm{C}$ and $800^{\circ} \mathrm{C}$ whith the peak around $770^{\circ} \mathrm{C}$ is due to the total decomposition of elements which began their decomposition during previous phases (Yoshio et al. 2003). At the end of pyrolysis analysis around 40,21\% of initial mass is not decomposed, this can correspond to the mass of rigid segment in the resin (formulation 2), all bonds within molecular rings are treated as rigid. 


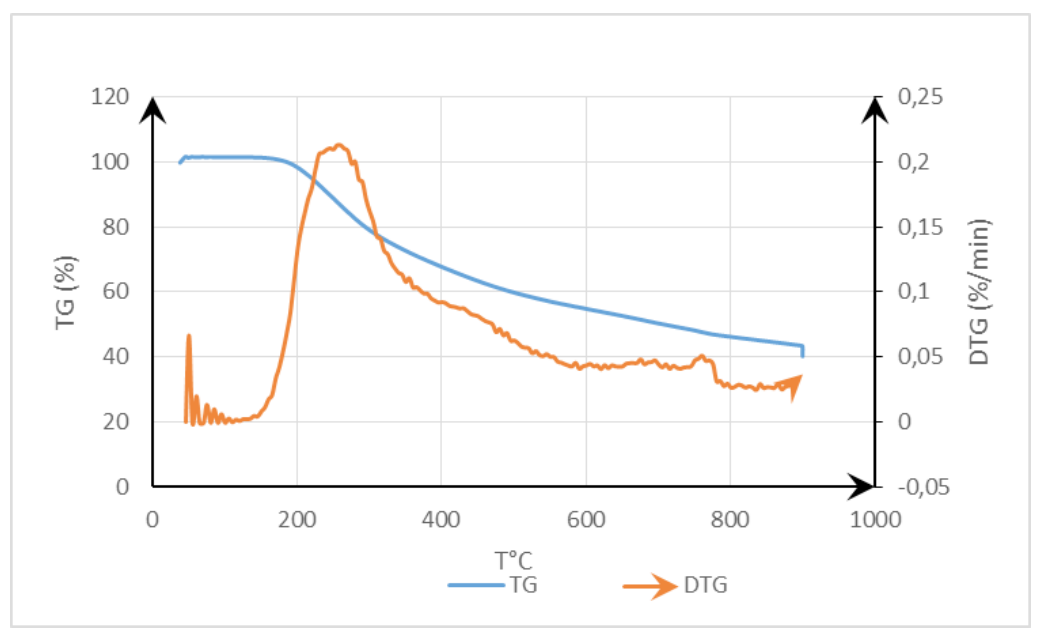

Figure 2. TG and DTG curves of pyrolysis analysis of aningre tannin resin under formulation 2.

\section{Pyrolysis of formulation 3}

Figure 3 shows TG and DTG curves of formulation 3 resin. Three main regions of mass loss are observed: In the first region between 40 and $140^{\circ} \mathrm{C}$ with the peak at $48^{\circ} \mathrm{C}$, we note the loss of water and small formation of volatile compounds $\left(\mathrm{CO}, \mathrm{H}, \mathrm{CO}_{2}\right)$ released by the resin and particularly by glyoxal. The second region of mass loss which occurs between 140 and $565^{\circ} \mathrm{C}$ with the peak at $245^{\circ} \mathrm{C}$ is due to the degradation of the laterals chains of the resin (Zhang et al. 2011) and the formation of volatile coumpounds ( $\mathrm{Lu} \mathrm{2008),} \mathrm{it} \mathrm{is} \mathrm{in} \mathrm{this} \mathrm{region} \mathrm{that} \mathrm{the} \mathrm{decomposition} \mathrm{of} \mathrm{glyoxal} \mathrm{is} \mathrm{observable.} \mathrm{Around}$ $470^{\circ} \mathrm{C}$, there is cleavage of $\mathrm{C}-\mathrm{C}$ bonds to form carbon and hydrogen as $\mathrm{CH}_{4}, \mathrm{CO}$ or $\mathrm{CO}_{2}$ (Gunes et al. 2009, Petrovich et al. 1994, Zhang et al. 2011). The third region between 735 and $845^{\circ} \mathrm{C}$ with the peak at $790^{\circ} \mathrm{C}$ is due to the decomposition of $\mathrm{A}$ and $\mathrm{B}$ ring flavonoid to form carbon skeleton. About $39,12 \%$ of initial mass is not total decomposed, this can correspond to the mass of rigid segment in the resin (formulation 3).

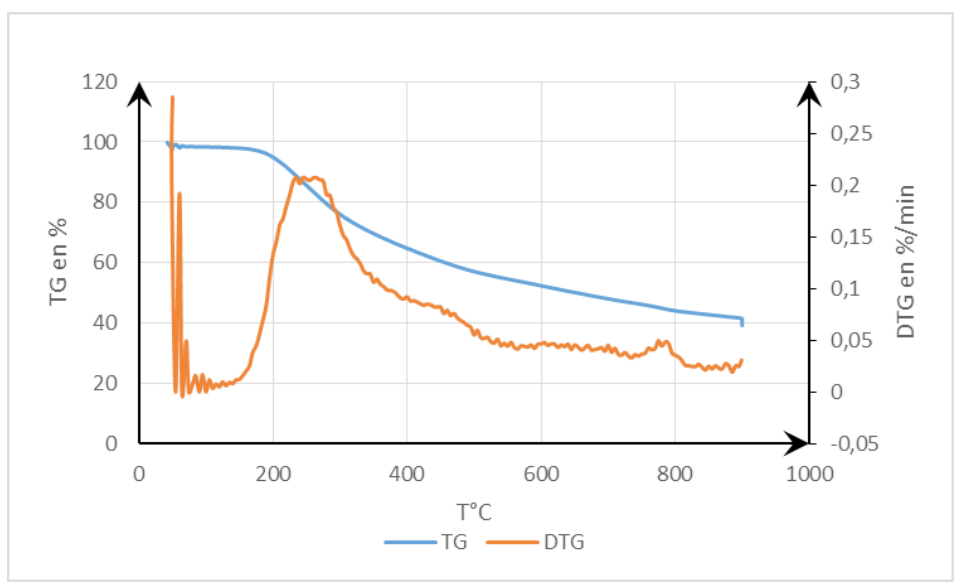

Figure 3. TG and DTG curves of pyrolysis analysis of aningre tannin resin under formulation 3 . 


\section{Comparative study}

Table 1 compares data of the resins analyzed. Residues obtained show that sample H (formulation 2) has lost less energy than GLY (formulation 3) and PF (formulation 1) samples; GLY sample loses less than PF (40,21>39,12> 24,01\%). The different slopes of the TG curves (series1) confirm these different degrees of weight loss. From these residues, it is appropriate to conclude that in resin $\mathrm{H}$ (formulation 1), there are more resistant segments to heat than in the GLY (formulation 3) and PF (formulation 1) samples. The molecular weight of hardeners confirms this [hexamethylenetetramine molecular weight $(140,18 \mathrm{~g} / \mathrm{mol})>$ glyoxal molecular weight $(58,03 \mathrm{~g} / \mathrm{mol})>$ paraformaldehyde molecular weight $(30,03$ $\mathrm{g} / \mathrm{mol})]$. The beginning of the degradation of the $\mathrm{H}$ sample $\left(145^{\circ} \mathrm{C}\right)$ is higher than those of $\mathrm{PF}(135$ $\left.{ }^{\circ} \mathrm{C}\right)$ and Gly $\left(140{ }^{\circ} \mathrm{C}\right)$; the low molecular weight of formaldehyde and its earlier decomposition than the others formulation $\left(135<140<145^{\circ} \mathrm{C}\right)$ explains the higher decomposition recorded by $\mathrm{PF}$ than the others formulations (2 and 3 ).

Table 1. Thermoanalytical data of samples.

\begin{tabular}{|c|c|c|c|c|}
\hline Analysis type & Samples & $\begin{array}{l}\text { Temperature } \\
\text { range }\left({ }^{\circ} \mathrm{C}\right)\end{array}$ & $\begin{array}{c}\text { Temperature } \\
\text { peak }\left({ }^{\circ} \mathrm{C}\right)\end{array}$ & $\begin{array}{c}\text { Residue samples } \\
\text { (\%) }\end{array}$ \\
\hline \multirow{9}{*}{ Pyrolysis } & \multirow{3}{*}{ Gly (formulation 3) } & $40-140$ & 48 & \multirow{3}{*}{39,12} \\
\hline & & $145-565$ & 245 & \\
\hline & & $735-845$ & 790 & \\
\hline & \multirow{3}{*}{$\mathrm{H}$ (formulation 2) } & $40-145$ & 49 & \multirow{3}{*}{40,21} \\
\hline & & $145-590$ & 250 & \\
\hline & & $590-800$ & 770 & \\
\hline & \multirow{3}{*}{ PF (formulation 1) } & $40-135$ & 49 & \multirow{3}{*}{24,01} \\
\hline & & $135-675$ & 255 & \\
\hline & & $675-765$ & 720 & \\
\hline
\end{tabular}

According to Figure 4 and 5 which recapitulate respectively the TG (H_pyro, PF_pyro, Gly_pyro) and DTG curves $\left(\mathrm{H}_{-}\right.$pyro, $\mathrm{PF}_{-}$pyro, Gly_ pyro), the biggest difference between these formulations occurs from $400^{\circ} \mathrm{C}$, it means that, the decomposition of the hardeners used (paraformaldehyde, aqueous glyoxal, hexamethylenetetramine) become more significant from $400{ }^{\circ} \mathrm{C}$ onward.(H_pyro, P_pyro, Gly_pyro mean respectively pyrolysis of $\mathrm{H}, \mathrm{PF}$ and Gly samples).

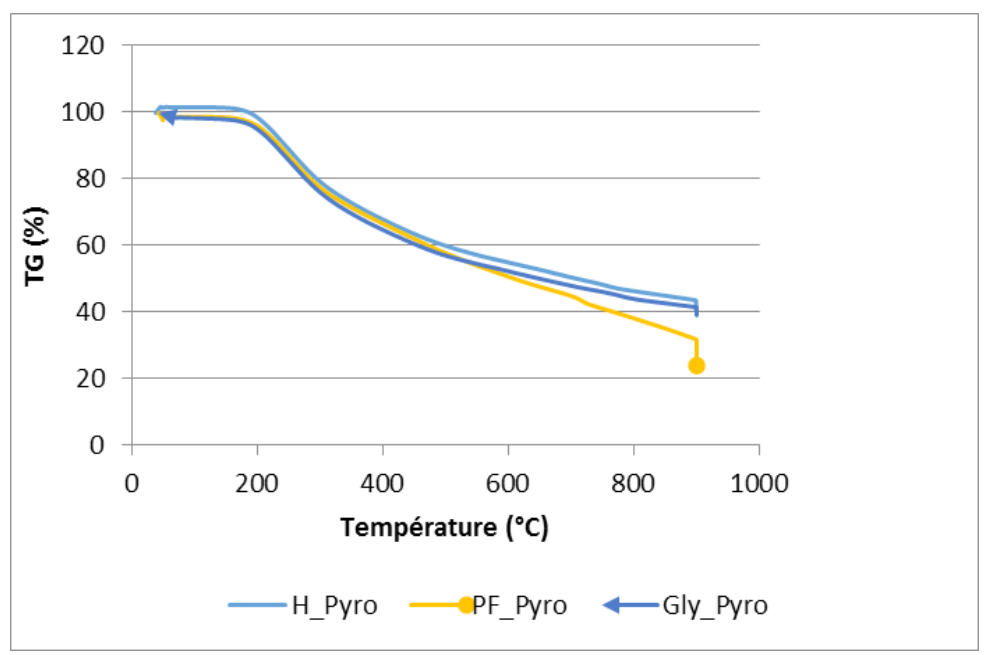

Figure 4. Recapitulation of TG curves. 


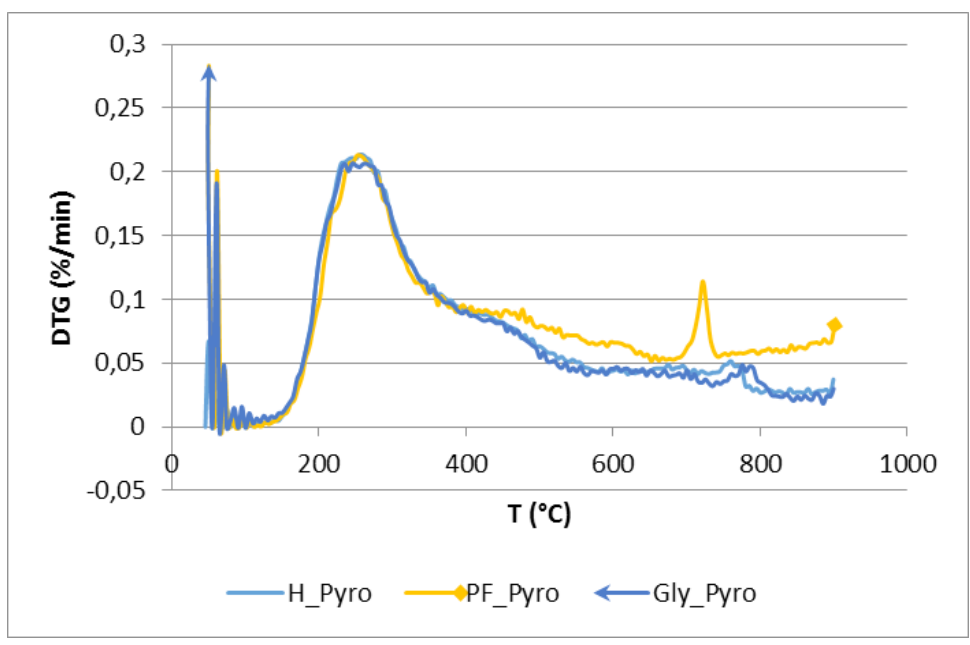

Figure 5. Recapitulation of DTG curves.

According to the Figure 6, PF, Gly and $\mathrm{H}$ formulations have respectively for rigidity 1190, 991 and $781 \mathrm{MPa}$. PF which has the smaller residues $(20 \%)$ after pyrolysis presents the best rigidity, the $\mathrm{H}$ formulation with its highest residues $(40 \%)$ has the worst rigidity $(1190>991>781 \mathrm{MPa})$.

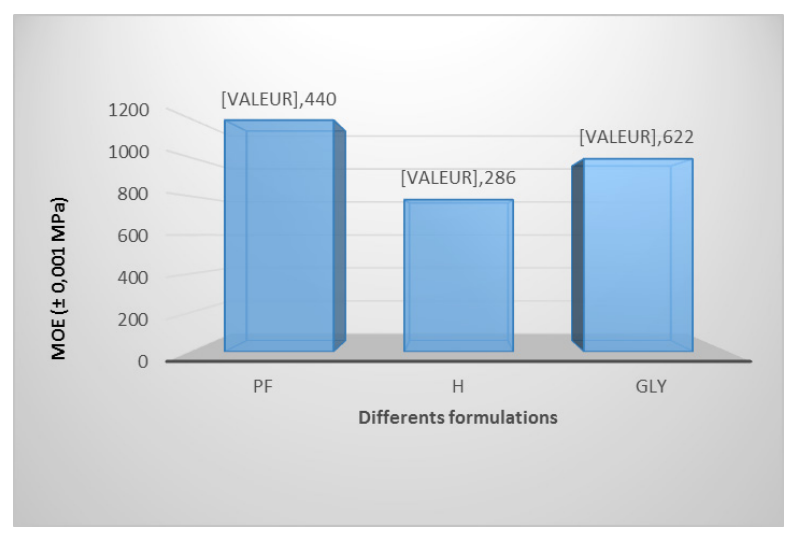

Figure 6. Comparison of resins rigidities.

\section{CONCLUSIONS}

Aningre tannin-based resins present a good future alternative for the wood industry, the heat resistance of various formulations being encouraging. The biggest difference between these formulations occurs from $400^{\circ} \mathrm{C}$ onward, the decomposition of hardeners used (paraformaldehyde, aqueous glyoxal, hexamethylenetetramine) become more significant from $400^{\circ} \mathrm{C}$ onward. 


\section{ACKNOWLEDGEMENTS}

My thanks to the French government for financing my stay at the LERMAB and at the University of Lorraine.

\section{REFERENCES}

Abdalla, S.; Pizzi, A. ; Bahabri, F.; Ganash, A. 2015. Furanic copolymers with synthetic and natural phenolic materials for wood adhesives - a maldi tof study. Maderas. Ciencia y Tecnología 17(1): 99-104.

Anachemia. 2012. Fiche signalétique [on line] < http://www.anachemia.com/msds/french/7020f. pdf. $>$ [accessed 09/03/2015].

Blazek, J. 2005. Study of the reaction kinetics of the thermal degradation of polymer. Thèse de Doctorat, Institut National Polytechnique de Toulouse. p.262.

Coppens, H. A.; Santana, M.A.E.; Pastore, F.J. 1980. Tannin formaldehyde adhesive for exterior - grade plywood and particleboard. Forest Prod J 30(4): 38-42.

Esteves, B. ; Martins, J. ; Martins, J. ; Cruz-Lopes, L.; Vicente, J.; Domingos, I. 2015. Liquefied wood as a partial substitute of melamine-urea-formaldehyde and urea-formaldehyde resins. Maderas.Ciencia y Tecnología 17(2):277-284.

Gunes, I.S.; Jimenez, A.G.; Jana, C.S. 2009. Carbonaceous fillers for shape memory actuation of polyurethane composites by resistive heating. Carbon 47: 981-987.

Kireche, Y. 2012. Extraction et Analyse de polyphénols de marcs de raisin Rapport de stage. Nancy. p.68.

Lin, R.; Sun, J.; Chao Yue, C.; Wang, X.; Tu, D.; Gao, Z. 2014. Study on preparation and properties of phenol-formaldehyde-chinese fir liquefaction copolymer resin. Maderas.Ciencia y Tecnología 16 (2):159-174.

Lu, J.; Wand, T.; Drzal, L.T. 2008. Preparation and properties of micro fibrillated cellulose polyvinyl alcohol composites materials. Applied Science and Manufacturing. Composite Part A 39(99):738-746.

Moubarik, A.; Ahmed, A.; Pizzi, A.; Fatima, C.; Bertrand, C. 2010. Preparation and mechanical characterization of particleboard made from maritime pine and glue with bio-adhesives based on cornstarch and tannin. Maderas. Ciencia y Tecnología 12(3):189-197.

Navarette, P.; Pizzi, A.; Bertaud, F.; Rigolet, S. 2011. Condensed tannin reactivity inhibition by internal rearrengements: detection by $\mathrm{CP}-\mathrm{MAS}{ }^{13} \mathrm{C}$ NMR. Maderas.Ciencia y Tecnología 13(1):5968 .

Petrovich, Z.S.; Zavargo, Z.; Flynn , J.H.; Macknight, W.J. 1994. Thermal degradation of segmented polyurethanes. J Appl Polym Sci 51:1087-1095. 
Pichelin, F.; Nakatani, M.; Pizzi, A.; Wieland, S.; Despres, A.; Rigolet, S. 2006. Structural beams from thick wood panels bonded industrially with formaldehyde - free tannin adhesives. Forest Prod J 56(5):31-36.

Pizzi, A. 1983. Wood adhesives chemistry and technology. New york, Marcel Dekker Inc, pp. 60-62.

Pizzi, A. 1994. Advanced Wood Adhesives technology. Marcel Dekker, New York .

Pizzi, A. 2006. Recent developments in eco - efficient bio - based adhesives for wood bonding: opportunities and issues. J Adhesion Sci Technol 20(8):829-846.

Pizzi, A.; Tekely, P. 1995. Mechanism of polyphenolic tannin resin hardening by hexamethylenetetramine: CP-MAS 13C NMR. J Appl Polym Sci 56: 1645-1650.

Reh, R.; Mihalik, A.; Osvald, A.; Krakovsky, A.; Kovacik, I. 1993. Thermal analyis of particleboard with, lower combustion. Technical University of Zvolen. Slovakia 16 (2): 214-223.

Sealy-Fisher, V.J.; Pizzi, A. 1992. Increased pine tannins extraction and wood adhesives development by phlobaphenes minimization. Holz als Roh-und Werkstoff 50: 212-220.

Yoshio Wang, M.; Lee, H.; Fukua, Y.S. 2003. Naphthalène sulfonate formaldehyde (NF - resin derived carbon beads as an anode material for Li - ion batteries. Electrochimical Acta 48:791-797.

Yuan, L.; Kaichang, L. 2007. Development and characterization of adhesives from soy protein for bonding wood. International Journal of Adhesion and Adhesives 27:59-67.

Zhang, W.; Yang, X.; Li, C.; Liang, M.; Luand, C.; Deng, Y. 2011. Mechanochemical activation of cellulose and its thermoplastic polyvinyl activation of cellulose and its thermoplastic polyvinyl alcohol eco composites with enhanced physicochemical properties. Carbohydrate Polymers 83(1): 257-263. 